\title{
THE SUSTAINABILITY OF TURKISH EXTERNAL DEBT: EVIDENCE FROM FRACTIONALLY INTEGRATED APPROACH UNDER STRUCTURAL BREAKS
}

\begin{abstract}
This paper examines the external debt sustainability in Turkey over the period 1970-2010 by using fractionally integrated approach. As a first step, possible structural breaks in the data are not taken into consideration. The findings from Robinson(1994a) test reveal that the process is nonstationary with long memory, therefore, there is no evidence of external debt sustainability in Turkey. In the second step, structural breaks identified by Bai and Perron $(1998,2003)$ multiple structural break test, are included in the Robinson test. The results in the context of structural breaks still show that the external debt in Turkey is not sustainable.
\end{abstract}

Keywords: External debt, Sustainability, Fractional integration, Multiple structural breaks.

\section{INTRODUCTİON}

The issue of external debt sustainability is widely debated in the theoretical and empirical literature since 1970s. This issue has become much more important since 1996, as debt relief initiatives for some low income countries have for the first time been based partly on the aim of making countries' debt "sustainable", rather than on the lowest common denominator of what creditors are willing to provide. Debt sustainability refers to a country's ability to service its borrowing, foreign and domestic, public and public guaranteed, private non-guaranteed, including both short and long term debt, without compromising its long term development goals and objectives. International Monetary Fund (IMF) describes the debt sustainability as follows: "a situation in which a borrower is expected to be able to continue servicing its debts without an unrealistically large correction to the balance of income and expenditure" (IMF, 2002).

A country's external debt is sustainable when two conditions are satisfied (Pradelli, 2006): (i) the expected foreign exchange flows associated with foreign trade and finance are balanced for a given time horizon, ii) the foreign exchange flow mismatches that may arise within that horizon are expected to be financed by international capital markets. These conditions are related to the solvency and liquidity notions. Here, it is important to note that solvency, liquidity and vulnerability are sub-components which debt sustainability incorporates. Solvency is a situation in which the present discounted value of the government's primary surpluses is greater than the present discounted value of its debt servicing. On the other hand, the liquidity is a situation in which the liquid assets and available private financings are sufficient to roll over its maturing liabilities while vulnerability is the risk that liquidity will be interrupted by an economic shock. In the model of external debt sustainability, a debtor country is solvent 
when it satisfies an intertemporal budget constraint.

There may be mainly three reasons for non-repayment of the external debt of a country (Eaton, 1989; Utkulu, 1994). These are illiquidity, insolvency and unwillingness to pay. Under the illiquidity approach, the debt crisis is temporary and it should be met by new financing arrangements designed to buy time until the situation improves. According to the solvency approach, the debtor country repays the debt as long as it is able to pay. Finally, the debtor country may be liquid and able to pay its debt, but unwilling to do it.

There are many alternative indicators for external debt sustainability in assessing insolvency. Three most commonly used indicators are the external debt to GDP ratio, the external debt to export ratio and the external debt to government revenues ratio (Roubini, 2001). In this ratios, a non-increasing external debt to GDP ratio is seen as a practical sufficient condition for sustainability. According to this condition, a country is likely to remain solvent as long as the ratio is not growing. If the debt to GDP ratio in a country is growing, the difference between the current trade balance and the trade surplus is required to stabilize the debt to GDP ratio. In order to stabilize this ratio, a larger trade surplus is required when a real depreciation increases the debt to GDP ratio. It can be stated that while a real depreciation increases the debt stock, it may also improve the external balance and does help to improve sustainability (Roubini, 2001).

While searching sustainability, the stationarity of the external debt is essential for the validity of the intertemporal budget constraint. Unit root and cointegration tests provide useful tools for implication of a government's or nation's intertemporal solvency. These tests determine whether a government or country is able to sustain its budget or external deficits without defaulting on its debt (Önel and Utkulu, 2006). In this point, Diebold and Rudebusch(1991) and Sowell(1990) argue that conventional unit root tests may have low power against fractional alternatives.

The aim of this paper is to examine the external debt sustainability of Turkey over the period 1970-2010. There are some studies in the literature which investigate the sustainability of the external debt for Turkey. Bahmani-Oskooee and Domac(1995) use a methodology to the growing Turkish external deficits and they are able to find evidence for external debt sustainability. Özatay $(1994,1997)$ examines the sustainability of the Turkish public sector deficits and fiscal policy and rejects the sustainability. Following the methodology of Hakkio and Rush(1991), Utkulu(1998) examines the long run tendency of the Turkish exports and imports and finds no evidence of cointegration between exports and imports implying that the external debt of Turkey is not sustainable. Önel and Utkulu(2006) investigate the external debt sustainability in Turkey by using usual intertemporal budget constraint in the contexts with and without structural breaks. They conclude that Turkish external debt is weakly sustainable. Mohammadi et al.(2007) search the extent of capital mobility and foreign debt sustainability in Turkey over the 1962-2003 period based on cointegration, error correction models and threshold and momentum threshold autoregressive models. Their findings are consistent with the existence of capital mobility and the strong form of foreign debt sustainability. 
The difference of this paper from the others is that the sustainability of Turkish external debt is investigated by means of fractionally integrated approach instead of classical approaches based on $I(0)$ or $I(1)$ integration. For this purpose, we use Robinson(1994a) test which has several distinguishing features compared with other procedures for unit and/or fractional roots. In particular, the test has a standard null limit distribution and it is the most efficient one when directed against the alternatives. This paper concentrates on the following points: First, we investigate the sustainability of the external debt without taking into account possible structural breaks in the data. Since Granger and Hyung(1999) and Diebold and Inoue(2001) argue that the long memory property in the data may be due to the presence of structural breaks or regime switches, in other words, the structural breaks and long memory properties are related concepts, we determine the potential structural breaks by using Bai and Perron $(1998,2003)$ multiple structural break test. Then, we also examine the Turkish external debt sustainability by taking into account determined structural breaks.

The plan of the paper is constructed as follows: Section 2 presents the fractional integration procedure of Robinson(1994a) and multiple structural break test of Bai and Perron $(1998,2003)$. Section 3 describes the data and gives empirical results. Finally, Section 5 contains conclusions.

\section{METHODOLOGY}

This section describes the Robinson(1994a) test for fractional integration and Bai and Perron $(1998,2003)$ test for multiple structural breaks.

\subsection{ROBINSON TESTS FOR FRACTIONAL INTEGRATION}

As reported before, the external debt sustainability of Turkey is investigated by using different versions of fractional integration test suggested by Robinson(1994a). The main advantage of this procedure is that it tests unit and fractional roots with a standard null limit distribution, which is unaffected by inclusion or not of deterministic trends. Robinson(1994a) considers the following regression model,

$$
y_{t}=\beta^{\prime} z_{t}+x_{t}, \quad t=1,2, \ldots
$$

where $y_{t}$ is the observed time series for $t=1,2, \ldots T, \beta=\left(\beta_{1}, \ldots, \beta_{k}\right)^{\prime}$ is a $(k \times 1)$ vector of unknown parameters, $z_{t}$ is a $(k \times 1)$ vector of deterministic regressors such as an intercept or a linear trend. And the regression errors $x_{t}$ can be explained as follows:

$$
(1-L)^{d} x_{t}=u_{t}, t=1,2, \ldots
$$

where $L$ is the lag operator and $u_{t}$ is an $I(0)$ process. Here, $d$ can take any real value. If $d>0$ ,$x_{t}$ is said to be long memory (Granger and Joyeux, 1980; Hosking, 1981). The process is nonstationary and exhibits long memory if $0.5<d<1$. Clearly, the unit root case corresponds to $d=1$ in (2). If $0<d<0.5$, the process is stationary and exhibits long memory. When $d<0.5$, the process is stationary as well as mean reverting with the effects of the shocks dying away in the long run. On the other hand, the process is non-stationary even if the fractional parameter is significantly less than 1 , when $0.5 \leq d$.

The Lagrange Multiplier (LM) test suggested by Robinson(1994a) tests unit roots and other 
forms of nonstationary hypotheses, embedded in fractional alternatives. The null hypothesis of the test is as follows:

$$
H_{0}: d=d_{0}
$$

The test statistic can be described by:

$$
\hat{r}=\frac{T^{1 / 2}}{\hat{\sigma}^{2}} \hat{A}^{1 / 2} \hat{a}
$$

Here, $T$ is the sample size and

$$
\begin{aligned}
& \hat{a}=\frac{-2 \pi}{T} \sum_{j=1}^{T-1} \psi\left(\lambda_{j}\right) g\left(\lambda_{j} ; \hat{\tau}\right)^{-1} I\left(\lambda_{j}\right) \quad \hat{\sigma}^{2}=\sigma^{2}(\hat{\tau})=\frac{2 \pi}{T} \sum_{j=1}^{T-1} g\left(\lambda_{j} ; \hat{\tau}\right)^{-1} I\left(\lambda_{j}\right) ; \\
& \hat{A}=\frac{2}{T}\left(\sum_{j=1}^{T-1} \psi\left(\lambda_{j}\right)^{2}-\sum_{j=1}^{T-1} \psi\left(\lambda_{j}\right) \hat{\varepsilon}\left(\lambda_{j}\right)^{\prime} \times\left(\sum_{j=1}^{T-1} \hat{\varepsilon}\left(\lambda_{j}\right) \hat{\varepsilon}\left(\lambda_{j}\right)^{\prime}\right)^{-1} \times \sum_{j=1}^{T-1} \hat{\varepsilon}\left(\lambda_{j}\right) \psi\left(\lambda_{j}\right)\right)
\end{aligned}
$$

$\mathrm{y}\left(\mathrm{I}_{\mathrm{j}}\right)=\log \left|2 \sin \frac{\mathrm{I}}{2}\right| ; \quad \hat{\varepsilon}\left(\lambda_{j}\right)=\frac{\partial}{\partial \tau} \log g\left(\lambda_{j} ; \hat{\tau}_{j}\right) ; \quad \lambda_{j}=\frac{2 \pi j}{T} ; \quad \hat{\tau}=\arg \min _{\tau \in T^{*}} \sigma^{2}(\tau)$

where $I\left(\lambda_{j}\right)$ is the periodogram of $u_{t}$ and $T^{*}$ is a compact subset or the Euclidean space.

Robinson(1994a) showed that the test statistic under certain regularity conditions is as below:

$\hat{r} \rightarrow{ }_{d} N(0,1)$ as $T \rightarrow \infty$.

Thus, a one sided 100a \% level test of Eq(3) against the alternative $H_{1}: d>d_{0}$ is given by the rule "Reject $H_{0}$ if $\hat{r}>z_{\alpha}$ " where the probability that a standard normal variate exceeds $Z_{\alpha}$ is a and conversely, a one sided 100a \% level test of Eq(3) against the alternative $H_{1}: d<d_{0}$ is given by the rule "Reject $H_{0}$ if $\hat{r}<-z_{\alpha}$ ".

Several works including Granger and Hyung(1999) and Diebold and Inoue(2001) argue that structural breaks or regime switchings can generate spurious long memory behaviour in an observed time series. In other words, the long memory property in the data may be due to the presence of structural breaks or regime switches. This is called "the spurious long memory process". In order to avoid spurious long memory problem, we also determine the possible structural breaks in the data by using Bai and Perron $(1998,2003)$ multiple structural break test.

\subsection{BAİ AND PERRON TESTS FOR MULTIPLE STRUCTURAL BREAKS}

Bai and Perron(1998, 2003) consider the following multiple structural break model with $m$ breaks ( $m+1$ regimes):

$$
\begin{aligned}
& y_{t}=x_{t}^{\prime} \beta+z_{t}^{\prime} \delta_{1}+u_{t}, \quad t=1, \ldots, T_{1} \\
& y_{t}=x_{t}^{\prime} \beta+z_{t}^{\prime} \delta_{2}+u_{t}, \quad t=T_{1}+1, \ldots, T_{2} \\
& y_{t}=x_{t}^{\prime} \beta+z_{t}^{\prime} \delta_{m+1}+u_{t}, \quad t=T_{m}+1, \ldots, T .
\end{aligned}
$$

where $y_{t}$ is the observed dependent variable at time $t, x_{t}$ is $(p \times 1)$ and $z_{t}$ is $(q \times 1)$ and $\mathrm{b}$ and $\mathrm{d}_{j}(j=1, \ldots, m+1)$ are the corresponding coefficient vectors, and $u_{t}$ is the disturbance term at time $t$. Here, $T$ is the sample size and $T_{1}<T_{2}<\ldots<T_{m}<T$. The break points $\left(T_{1}, \ldots, T_{m}\right)$ 
are treated as unknown and are estimated together with the unknown coefficients when $T$ observations are available. The estimation method is based on least squares principle. For each $m$-partition $\left(T_{1}, \ldots, T_{m}\right)$, denoted $\left\{T_{j}\right\}$, the associated least squares estimate of $\mathbf{d}_{j}$ is obtained by minimizing the sum of squared residuals

$$
\sum_{i=1}^{m+1} \sum_{t=T_{*-1}+1}^{T_{i}}\left(y_{t}-z_{t}^{\prime} \delta_{i}\right)^{2}
$$

Bai and Perron(1998, 2003) suggest several statistics for consistent estimation of the number and location of breakpoints $\left(T_{1}, \ldots, T_{m}\right)$ and the parameters $\left(\mathrm{d}_{1}^{\prime}, \ldots, \mathrm{d}_{m+1}^{\prime}\right)$ :

- $\quad \operatorname{SupF}_{T}(k)$ test, i.e., a $S u p F$ - type test of the null hypothesis of no structural break versus the alternative of a fixed number of breaks $k$.

- Two maximum tests of the null hypothesis of no structural break versus the alternative of an unknown number of breaks given some upper bound, i.e., $U D_{\max }$ test, an equal weighted version, and $W D_{\max }$ test, with weights that depend on the number of regressors and the significance level of the test.

- $\quad$ The $\operatorname{SupF}_{T}(I+1 \mid I)$ test, i.e., a sequential test of the null hypothesis of $l$ breaks versus the alternative of $(l+1)$ breaks.

The asymptotic distributions of these three tests are derived in Bai and Perron(1998) and asymptotic critical values are tabulated in Bai and Perron $(1998,2003)$ for $e=0.05(M=9), 0.10$ $(M=8), 0.15(M=5), 0.20(M=3)$, and $0.25(M=2)$. The procedure of Bai and Perron follows these steps: First, calculate the $U D_{\max }$ and $W D_{\max }$ statistics. These tests are used to determine if at least one structural break is present. In addition, the $\operatorname{SupF}_{T}(k)$ test is calculated for the hypothesis of 0 break versus $k$ breaks. If these tests show evidence of at least one structural break, then the number of breaks can be determined by the $\operatorname{SupF}_{T}(l+1 \mid l)$ test. The number of breaks can also be chosen by the Bayesian information criterion, BIC (Yao, 1988); and the Schwarz modified criterion, LWZ (Liu, Wu and Zidek, 1997).

\section{DATA AND EMPİRİCAL RESULTS}

This paper investigates the sustainability of external debt in Turkey by using external debt to GDP ratio (\%) over the period from 1970 through 2010. The annual data is obtained from the World Development Indicators database of World Bank and Economic and Social Indicators database of Ministry of Development of Turkish Republic. The plot of the external debt to GDP ratio can be seen in Figure 1. 
Figure 1: The plot of the external debt to GDP ratio (\%)

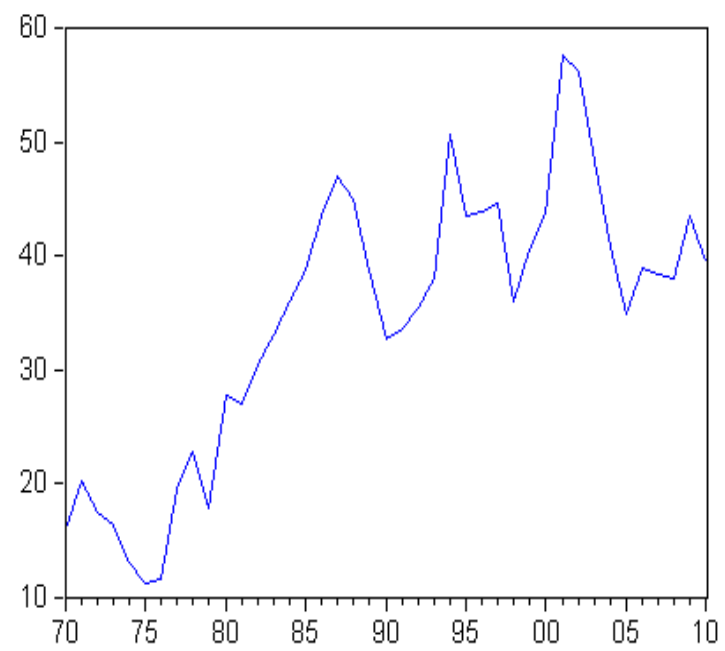

As can be seen from the figure, the ratio of external debt to GDP shows a nonstationary behavior and includes structural breaks. Since the plot is only suggestive of the behavior of the series, we focus on this in the context of different techniques. Before the analysis, it is considered that descriptive statistics and Augmented Dickey Fuller (ADF) and Philips and Perron (PP) unit root tests give some information about the series. Table 1 reports the descriptive statistics and the results of the mentioned unit root tests.

Table 1: Descriptive statistics and unit root test results for the ratio of external debt to GDP

\begin{tabular}{lc}
\hline Panel A: Descriptive statistics & \\
\hline Mean & 34.47 \\
Median & 38.00 \\
Maximum & 57.60 \\
Minimum & 11.30 \\
Standard deviation & 12.15 \\
Skewness & -0.364 \\
Kurtosis & 2.322 \\
Jarque Bera statistic & 1.692 \\
Probability & 0.429
\end{tabular}

Panel B: Unit root test results
ADF
Level: -1.99
PP
First differences: $-5.89^{* * *}$
Level: -2.125
First differences: $-5.90^{* * *}$

The Jarque Bera corresponds to the test statistic for the null hypothesis of normality.

${ }^{* * *}$ indicates the rejection of the unit root null hypothesis at the $1 \%$ significance level. 
Panel A of the table shows that the mean, median, maximum, minimum and standard deviation of the external debt to GDP ratio are $34.47,38,57.60,11.30$ and 12.15 respectively. The skewness (-0.364) and kurtosis (2.322) values are close to the skewness (0) and kurtosis (3) values for normal distribution. According to the Jarque Bera statistic (1.692), the distribution of the series is found normal. Additionally, Panel B of Table 1 provides the results of ADF and PP unit root tests. The results show that the ratio of external debt to GDP is nonstationary in level. Large negative values for the ADF and PP test statistics reject significantly the unit root null hypothesis, implying that the ratio of external debt to GDP is stationary after first differencing. Since the concept of traditional unit root tests are too restrictive, we consider to investigate the sustainability of the external debt for Turkey by using different versions of Robinson(1994a) test. As a first step in our analysis, we examine the Turkish external debt sustainability without taking into account possible structural breaks in the data. Under the null hypothesis $H_{0}(3)$, we examine the cases with an intercept and a linear time trend and model the $I(0)$ disturbances to be AR(1) process. In Robinson test, significantly positive values of $\hat{r}$ are consistent with the orders of integration higher than $d_{0}$, whereas significantly negative ones consistent with the orders of integration smaller than $d_{0}$. A notable feature is the fact that $\hat{r}$ monotonically decreases with $d_{0}$ since it is a one sided test statistic. The one sided test statistics $\hat{r}$ with $d_{0}=0,0.05,0.10,0.15,0.20,0.25, \ldots . ., 1.10$, thus testing for a unit root $(d=1)$, but also including a test for stationarity ( $d=0.5$ ) and for other fractional alternatives are reported in Table 2.

Table 2: Robinson test results under AR(1) disturbances before determining structural breaks

\begin{tabular}{|c|c|c|}
\hline$d_{0}$ & An intercept & Linear trend \\
\hline 0 & 24.676 & 12.293 \\
\hline 0.05 & 23.259 & $\begin{array}{l}11.293 \\
11.36\end{array}$ \\
\hline 0.10 & 21.666 & 10.358 \\
\hline 0.15 & 19.887 & 9.428 \\
\hline 0.20 & 17.951 & 8.533 \\
\hline 0.25 & 15.925 & 7.680 \\
\hline 0.30 & 13.892 & 6.873 \\
\hline 0.35 & 11.938 & 6.112 \\
\hline 0.40 & 10.127 & 5.395 \\
\hline 0.45 & 8.500 & 4.717 \\
\hline 0.50 & 7.067 & 4.074 \\
\hline 0.55 & 5.816 & 3.458 \\
\hline 0.60 & 4.719 & 2.863 \\
\hline 0.65 & 3.742 & 2.281 \\
\hline 0.70 & 2.848 & 1.708 \\
\hline 0.75 & 2.006 & $1.138^{* *}$ \\
\hline 0.80 & $1.192^{* *}$ & $0.570^{* *}$ \\
\hline 0.85 & $0.394^{* *}$ & $0.004^{* * *}$ \\
\hline 0.90 & $-0.388^{* *}$ & $-0.558^{* *}$ \\
\hline 0.95 & $-1.142^{* *}$ & $-1.112^{* *}$ \\
\hline 1.00 & -1.851 & -1.653 \\
\hline 1.05 & -2.501 & -2.175 \\
\hline 1.10 & -3.08 & -2.674 \\
\hline
\end{tabular}

In bold: The smallest value across the different values of $d_{0}{ }^{* *}$ indicates nonrejection values of the null hypothesis at the $95 \%$ significance level.

According to the results in the table, $H_{0}(3)$ cannot be rejected for ${ }_{0}=0.80,0.85,0.90$ and 0.95 in the case of intercept. On the other hand, the non-rejection values take place at 
$\boldsymbol{d}_{\mathrm{o}}=\mathbf{0 . 7 5}, \mathbf{0 . 8 0}, \mathbf{0 . 8 5}, \mathbf{0 . 9 0}$ and 0.95 . The lowest statistic across the different values of $d_{0}$ occurs when $d_{0}=0.90$ in the intercept case and when $d_{0}=0.85$ in the trend case. These findings indicate that the ratio of external debt to GDP is a non-stationary process with long memory when we ignore potential structural breaks in the data. Therefore, it can be concluded that Turkish external debt is not sustainable. It is known that Granger and Hyung(1999) and Diebold and Inoue(2001) claim the long memory property in the data may be due to the presence of structural breaks or regime switches. Since the structural breaks and long memory properties are related concepts, we consider that the ratio of external debt to GDP may be affected by structural breaks over the sample period and determine potential structural breaks by using Bai and Perron $(1998,2003)$ multiple structural break test. This procedure allows to test for multiple breaks at unknown dates, so that each break point is successively estimated by using a specific-to-general strategy in order to determine consistently the number of breaks. The maximum permitted number of breaks is set at $M=5$ and a trimming $\mathrm{e}=0.15$ is used to determine the minimal number of observations in each segment $[h=[\varepsilon T]$ with the sample size $\mathrm{T}]$. The finding results by implementing a Gauss programme are tabulated in Table 3.

Table 3: The results of Bai and Perron tests

\section{$\underline{\text { Specifications }}$}

$$
z_{t}=1 \quad q=1 \quad p=0 \quad h=6 \quad M=5 \quad \mathrm{e}=0.15
$$

$\begin{array}{lll}\text { Tests } & \text { Hypothesis } & \text { Statistics } \\ \text { SupF } & \text { (k) Test: } & \\ & H_{0}: 058^{* * *} \\ & H_{1}: 1 \text { break } v s & \\ & H_{0}: 0 \text { break } v s & 22.047^{* * *} \\ & H_{1}: 2 \text { breaks } & \\ & H_{0}: 0 \text { break } v s & 25.047^{* * *} \\ & H_{1}: 3 \text { breaks } & \\ & H_{0}: 0 \text { break } v s & 14.927^{* * *} \\ & H_{1}: 4 \text { breaks } \\ & H_{0}: 0 \text { break } v s & \\ & H_{1}: 5 \text { breaks } \\ & H_{0}: 0 \text { break } v s & \\ & H_{1}: \text { an unknown break } & \\ \text { UD }_{\text {max }} \text { Test: } & H_{0}: 0 \text { break } v s & \\ \text { WD }_{\text {max }} \text { Test: } & H_{1}: \text { an unknown break } & \end{array}$


$\operatorname{SupF}_{T}(1+1 \mid$ l) Test:

Number of Breaks:

Break Dates:
$\operatorname{SupF}_{\mathrm{T}}(2 \mid 1)$

$\operatorname{SupF}_{\mathrm{T}}(3 \mid 2)$

$\operatorname{SupF}_{\mathrm{T}}(4 \mid 3)$

$\operatorname{SupF}_{\mathrm{T}}(5 \mid 4)$

BIC: 2

1979 and 1985
1.446

0.413

0.077

0.000

${ }^{* * *}$ denotes that the tests are significant at $1 \%$ level.

The reported results in the table indicate that all the $\operatorname{SupF}_{T}(k)$ tests are significant, with $k$ running between 1 and 5 , so that at least one break would be present. On the other hand, both $U D_{\max }$ and $W D_{\max }$ statistics are highly significant which implies that at least one break is present in the data. Since the significance of these tests does not provide enough information about the exact number of breaks, we try to choose number of breaks by using $\operatorname{SupF}_{T}(l+1 \mid l)$ test or the BIC criterion. All the $\operatorname{Sup}_{T}(l+1 \mid l)$ statistics are found insignificant. After that we choose the number of break as 2 by using BIC criterion. The break dates are identified around 1979 and 1985. The first break refers to the structural change reform in Turkey. It is known that the date of January 1980 was a turning point for Turkish economy. In this time, import substitute industrialization strategy was replaced by an export-led growth strategy that relies more on the market-based economy. The policies based on adjustments upon tariffs rather than quantity restrictions were adopted, and also protection rates in imports regime were steadily lowered. Besides, export licenses were abolished, and export liberalization was put in effect as a major policy issue in the Turkish economy politics (Varol, 2003). So, the ratio of external deficit to GDP fell from 7 percent in 1980 to 1 percent in 1988. On the other hand, the second break refers to the years when Turkey's external debt stock increased. In 1982, it was 17.2 billion dolar, then it reached 25.6 billion dolar in 1985 . We need to take into account these breaks in the analysis. Robinson(1994a) test permits us to include structural breaks in the model with no effect on its standard limit distributions. Following this way, we construct the dummy variables for the break dates $\left(T_{B}\right)$ of $1979\left(D_{1979}\right)$ and $1985\left(D_{1985}\right)$ as below:

$D_{1979}=\left\{\begin{array}{l}1 \text { for } I\left(t>T_{B}\right), T_{B}=1979 \\ 0 \text { otherwise }\end{array}, D_{1985}= \begin{cases}1 & \text { for } I\left(t>T_{B}\right), T_{B}=1985 \\ 0 & \text { otherwise }\end{cases}\right.$

Then, we again apply the Robinson(1994a) tests in the cases with an intercept and a linear trend by including constructed dummy variables in the following model:

External Debt $/ G D P_{t}=\beta_{0}+\beta_{1} t+\beta_{2} D_{1979}+\beta_{3} D_{1985}+X_{t} \quad, \quad t=1,2, \ldots$

By obtaining $x_{t}$ regression errors, the equation is constructed as below:

$(1-L)^{d} x_{t}=u_{t} \quad, \quad t=1,2, \ldots$

Then, the one sided test statistics $\hat{r}$ are calculated and their results are reported in Table $4^{2}$.

2 Since the BIC criterion in the Bai Perron multiple structural break test gives two significant breaks in 1979 and 1985 , we also 
Table 4: Robinson test results under AR(1) disturbances after including structural breaks

\begin{tabular}{|c|c|c|}
\hline$d_{0}$ & An intercept & Linear trend \\
\hline 0 & 5.501 & 5.447 \\
\hline 0.05 & 5.075 & 5.035 \\
\hline 0.10 & 4.668 & 4.641 \\
\hline 0.15 & 4.278 & 4.260 \\
\hline 0.20 & 3.904 & 3.893 \\
\hline 0.25 & 3.542 & 3.537 \\
\hline 0.30 & 3.191 & 3.190 \\
\hline 0.35 & 2.849 & 2.851 \\
\hline 0.40 & 2.514 & 2.518 \\
\hline 0.45 & 2.184 & 2.190 \\
\hline 0.50 & 1.856 & 1.864 \\
\hline 0.55 & $1.530^{* *}$ & $1.538^{* *}$ \\
\hline 0.60 & $1.203^{* *}$ & $1.212^{* *}$ \\
\hline 0.65 & $0.874^{* *}$ & $0.883^{* *}$ \\
\hline 0.70 & $0.541^{* *}$ & $0.551^{* *}$ \\
\hline 0.75 & $0.204^{* *}$ & $0.213^{* *}$ \\
\hline 0.80 & $-0.140^{* * *}$ & $-0.130^{* * *}$ \\
\hline 0.85 & $-0.489^{* *}$ & $-0.478^{* *}$ \\
\hline 0.90 & $-0.844^{* *}$ & $-0.833^{* *}$ \\
\hline 0.95 & $-1.203^{* *}$ & $-1.192^{* *}$ \\
\hline 1.00 & $-1.566^{* *}$ & $-1.555^{* *}$ \\
\hline 1.05 & -1.931 & -1.920 \\
\hline 1.10 & -2.294 & -2.283 \\
\hline
\end{tabular}

In bold: The smallest value across the different values of $d_{0}$.** indicates nonrejection values of the null hypothesis at the $95 \%$ significance level.

The results in the table show that the non-rejection values take place at $d_{0}=0.55,0.60,0.65,0.70,0.75,0.80,0.85,0.90$ and 1 and the smallest statistic across the different values of $d_{0}$ occurs when $d_{0}=0.80$ in both cases with an intercept and a linear trend. These results mean that we still find evidence of nonstationary long memory behavior in the ratio of external debt to GDP after including the effects of structural breaks in the models. Therefore, there is no evidence of sustainability in the external debt of Turkey. This finding indicates the ineffectiveness of fiscal, monetary and exchange rate policies of Turkey. For a sustainable debt apply Lee and Strazicich(2003a, b) minimum LM unit root test with two structural breaks and find significant breaks in 1983 and 2000. After detrending these breaks, we again repeat the Robinson test and find that the non-rejection values take place at $d_{0}=0.55,0.60,0.65,0.70,0.75$ and 0.80 and the smallest statistic across the different values of $d_{0}$ occurs when $d_{0}=0.70$ in both cases with an intercept and a linear trend. According to these results, it can be said that external debt in Turkey is not sustainable. These results are not reported here but they can be given on request. 
strategy, preventing a debt crisis is a crucial policy concern. External debt crises prevention hinges on one condition, that the debt payment capacity of debtor countries is fully supported by its export capacity. Hence, trade plays a critical role in external debt sustainability of Turkey. On the other hand, Turkey should also build and improve institutional framework for debt management. Within this framework, it is important to assign specific roles and responsibilities to different government entities: the ministry of finance, the central bank and the debt management agency. This framework should be adapted to the administrative capacity of Turkey.

\section{CONCLUSIONS}

This paper investigates the sustainability of Turkish external debt in the context of fractionally integrated approach over the period from 1970 through 2010. In the first step of the analysis, the Robinson(1994a) test for fractional integration is applied without taking into account possible structural breaks in the data. The results show that ratio of external debt to GDP is a non-stationary process with long memory when the potential structural breaks are ignored. In this case, the sustainability of the Turkish external debt is not valid. Since Granger and Hyung(1999) and Diebold and Inoue(2001) argue that the long memory property in the data may be due to the presence of structural breaks or regime switches, we consider to determine possible structural breaks by using Bai and Perron $(1998,2003)$ multiple structural break test in the second step. According to the BIC criterion of the test, two break dates are identified around 1979 and 1985. By including the dummy variables for these breaks, we again repeat the Robinson(1994a) test. In the context of structural breaks, the findings still indicate that the ratio of external debt to GDP follows nonstationary long memory behavior. It can be concluded that the external debt of Turkey is not sustainable. This kind of finding shows that fiscal, monetary and exchange rate policies in Turkey is not effective. For a sustainable debt strategy, Turkey should prevent debt crises by improving her trade capacity. In addition, Turkey should also build and improve institutional framework for debt management by assigning specific roles and responsibilities to different government entities: the ministry of finance, the central bank and the debt management agency. 


\section{REFERENCES}

Bahmani-Oskooee, M. and Domac, I., (1995), "The Long-Run Relation between Imports and Exports in an LDC: Evidence from Turkey”, METU Studies in Development, 22: 177-189.

Bai, J. and Perron, P., (1998), "Estimating and Testing Linear Models with Multiple Structural Changes", Econometrica, 66: 47-78.

Bai, J. and Perron, P., (2003), “Computation and Analysis of Multiple Structural Change Models”, Journal of Applied Econometrics, 18: 1-22.

Diebold, F.X. and Inoue, A., (2001), "Long Memory and Regime Switching", Journal of Econometrics, 105: 131-159.

Diebold, F.X. and Rudebusch, G.D., (1991), “On the Power of Dickey-Fuller Tests Against Fractional Alternatives", Economics Letters, 35: 155-160.

Eaton, J., (1989), Foreign Public Capital Flows, In: Chenery, H., Srinivasan, T.N. (Eds) Handbook of Development Economics, 2, North Holland.

Granger, C.W.J. and Hyung, J., (1999), “Occasional Structural Breaks and Long Memory”, Discussion Paper, 99-14, University of California, San Diego.

Granger, C.W.J. and Joyeux, R., (1980), “An Introduction to Long-Memory Time Series Models and Fractional Differencing", Journal of Time Series Analysis, 1: 15-29.

Hakkio, C.S. and Rush, M., (1991), “Is the Budget Deficit Too Large?”, Economic Inquiry, 29: 429-445.

Hosking, J., (1981), “Fractional Differencing”, Biometrika, 68: 165-176.

IMF, (2002), "Assessing Sustainability, prepared by the Policy Development and Review Department", 28 May, IMF, Washington DC.

Lee, J. and Strazicich, M.C., (2003a), "Minimum LM Unit Root Test with One Structural Break", Mimeo, University of Central Florida.

Lee, J. and Strazicich, M.C., (2003b), "Minimum Lagrange Multiplier Unit Root Test with Two Structural Breaks", Review of Economics and Statistics, 85: 1082 - 1089.

Liu J., Wu, S. and Zidek, J.V., (1997), “On Segmented Multivariate Regressions”, Statistica Sinica, 7: 497-525.

Mohammadi, H., Çak, M. and Çak, D., (2007), “Capital Mobility and Foreign Debt Sustainability: Some Evidence from Turkey”, Applied Economics, 39: 2441-2449.

Önel, G., and Utkulu, U., (2006), "Modeling the Long Run Sustainability of Turkish External Debt with Structural Breaks", Economic Modelling, 23: 669-682.

Özatay, F., (1994), “The Sustainability of Public Sector Deficits: The Case of Turkey”, The Central Bank of the Republic of Turkey, Research Department, Discussion Papers, No:9402, Ankara.

Özatay, F., (1997), “The Sustainability of Fiscal Deficits, Monetary Policy and Inflation Stabilization", Journal of Policy Modelling, 19: 661-681.

Pradelli, J.J., (2006), “On External Debt Sustainability and the Argentine Crisis”, (Online) http://193.205.83.2/ confeco/papers/pradelli.pdf

Robinson, P.M., (1994a), "Efficient Tests of Nonstationary Hypothesis”, Journal of the American Statistical Association, 89: 1420-1437.

Roubini, N., (2001), "Debt Sustainability: How to Assess Whether a Country is Insolvent", 
Processed, December 20, Stern School of Business, New York University, New York.

Sowell, F., (1990), “Fractional Unit Root Distribution”, Econometrica, 50: 495-505.

Utkulu, U., (1994), "LDC External Debt, Trade and Solvency of a Nation: Time-Series Evidence for Turkey”, Ph.D. Thesis, Economics Depatment, Leicester University.

Utkulu, U., (1998), "Are the Turkish External Deficits Sustainable? Evidence from the Cointegrating Relationship Between Exports and Imports”, DEU. IIBF. Dergisi, 13: 119-132.

Varol, G. M., (2003), “Cumhuriyetin 80. Yılında Türk Dış Ticaretinin Kısa Tarihçesi”, DTM dergisi, (Online) http://www.dtm.gov.tr/ead/DTDERGI/ozelsayiekim/muge.htm.

Yao, Y.C., (1988), "Estimating the Number of Change-Points via Schwarz' Criterion”, Statistics and Probability Letters, 6: 181-189.

\section{ODRŽIVOST TURSKOG VANJSKOG DUGA: DOKAZI FRAKCIONARNO INTEGRIRANOG PRISTUPA PRI STRUKTURNIM PREKIDIMA}

\section{Sažetak}

Rad istražuje održivost vanjskog duga Turske u periodu od 1970. do 2010. koristeći frakcionarno integrirani pristup. Prije svega, mogući strukturni prekidi u podacima se ne uzimaju u obzir. Razultati Robinsonovog (1994a) testa otkrivaju da je proces nestacionaran s dugom memorijom i stoga nema dokaza održivosti vanjskog duga Turske. Nakon toga, strukturni prekidi uočeni Bai i Perron $(1998,2003)$ višestrukim testom strukturnog prekida, uključeni su u Robinsonov test. Rezultati u kontekstu strukturnih prekida još uvijek pokazuju da je vanjski dug Turske neodrživ.

Ključne riječi: Vanjski dug, održivost, frakcionarna integracija, višestruki strukturni prekidi. 